\title{
Preventing falls and subsequent injury in older people
}

\author{
Ann Oakley, Merry France Dawson, Janet Holland, Sean Arnold, Colin Cryer, \\ Yvonne Doyle, John Rice, Christine Russell Hodgson, Amanda Sowden, Trevor Sheldon, \\ Deirdre Fullerton, Ann-Marie Glenny, Alison Eastwood
}

This paper is based on Effective Health Care, Vol 2, No 4

\section{Social Science Research Unit, University of London Institute of Education London WC1H ONS Ann Oakley, director Merry France Dawson, research officer Janet Holland, senior research officer Sean Arnold, research officer}

\section{South East Institute} for Public Health, UMDS, University of London, Tunbridge Wells. TN3 0XT

Colin Cryer, statistician and injury research team leader

Yvonne Doyle, director of public health

John Rice, director of environmental research group

Christine Russell

Hodgson, research fellow

\section{NHS Centre for}

Reviews and

Dissemination,

University of York,

York. Y01 5DD

Amanda Sowden,

research fellow

Trevor Sheldon, director

Deirdre Fullerton,

research fellow

Ann-Marie Glenny,

research fellow

Alison Eastwood,

research fellow

Correspondence to:

Professor Trevor A Sheldon, NHS Centre for Reviews and Dissemination, University of York, York. Y01 5DD
This paper is based on Effective Health Care, Vol 2, No 4, which is a systematic review of the evidence for the effectiveness of interventions to prevent falls and subsequent injury in older people. ${ }^{1}$ The relevant literature was identified by a search of several computerised databases (Social Science Citation Index (BIDS), PSYCHLIT, EMBASE, RCN database, AMED, and UNCOVER), citation in identified papers and previous reviews, and contributions from peer reviewers and other experts in the field. Only randomised controlled trials evaluating the effectiveness of preventive interventions which measured the effect on falls, injuries related to falls, or change in a risk factor for falls were included.

\section{Background}

In 1991 in the United Kingdom about one in six people were over 65 years of age, and by 2021 this proportion is expected to be nearly one in five. ${ }^{2}$ Accidents are a major health problem among older people ${ }^{34}$ with falls, traffic accidents, and burns the main causes of accidental death. ${ }^{5}$ Of these categories, falls are the leading cause of death from injury among people aged over $75^{5}$ and over $85 \%$ of all fatal falls in the home in England and Wales are in people aged over $65 .^{6}$ About one third of the population over 65 years of age and more than half of the women over 85 years living at home (and a greater proportion of those in institutional settings) will fall at least once every year. ${ }^{578}$ Reducing the death rate from accidents in people aged 65 and over by at least $33 \%$ by the year 2005 is a specific target in the United Kingdom Department of Health's strategy Health of the Nation. ${ }^{4}$

\section{Identifying older people at risk}

There are many epidemiological studies which have identified several potential risk factors for falls. ${ }^{5-12}$ At present, however, there is no agreed and reliable set of risk factors for falls and subsequent injury, although it is widely recognised that the causes of falls are often multifactorial. ${ }^{6}$ Some of the most often cited potential risk factors are nutritional status such as vitamin $\mathrm{D}$ and calcium deficiency; environmental hazards such as loose carpets in the home; prescribed medications; lack of exercise (associated with weak muscles and poor balance) and age related changes such as a deterioration in vision.

\section{Effectiveness of interventions to reduce the risk of falling}

EXERCISE

The question of whether short term exercise reduces falls in older people has been specifically considered in the frailties and injuries cooperative studies of intervention techniques (FICSIT) programme of randomised controlled trials in the United States. ${ }^{13}$ Two of the trials ${ }^{1415}$ were carried out in nursing homes and five were community based and participants had to be at least 60 years of age. ${ }^{16-20}$ Seven of the trials included an exercise component, for a duration of 10-24 weeks, which was sometimes combined with other interventions. Participants were followed up from two to four years after the intervention (table 1).

In a meta-analysis of these trials, participants who were assigned to exercise groups had an estimated $10 \%$ lower risk of falling than controls (adjusted fall incidence ratio $(\mathrm{IR})=0.90 ; 95 \%$ confidence interval $(95 \% \mathrm{CI})$ $0.81-0.99 ; \mathrm{P}=0.04) .^{13}$ When the results from trials in which balance training was the only intervention, were pooled, a $25 \%$ reduction in the risk of falling was found (IR=0.75, $\mathrm{P}=0.01$ ). In one trial of community dwellers of average age 75 those receiving Tai Chi classes (a balance exercise) had a 37\% lower risk of falling than the control group ( $\mathrm{IR}=0.63 ; 95 \%$ CI 0.44-0.89). ${ }^{13}$

Because the study participants were generally healthier and better educated than average it is not clear whether the results could be generalised to a typical older population. ${ }^{21}$ One of the trials, for example, which evaluated balancing and resistance exercises in an unrepresentative healthy and well off group of older people found no effect of the intervention. ${ }^{20}$

Table 2 shows the results of other randomised controlled trials which have evaluated exercise only interventions in the prevention of falls. ${ }^{22-24}$ In one study, where the aim 
Table 1 Exercise interventions of the FICSIT trials *

\begin{tabular}{|c|c|c|c|c|c|c|c|}
\hline & $\begin{array}{l}\text { Site } 1 \text { (Hornbrook } \\
\text { et al 1993) }\end{array}$ & $\begin{array}{l}\text { Site } 2 \text { (Tinetti et al } \\
1994)^{17}\end{array}$ & $\begin{array}{l}\text { Site } 3 \text { (Buchner et } \\
\text { al 1993) }\end{array}$ & $\begin{array}{l}\text { Site } 4 \text { (Mulrow et al } \\
\text { 1994) }\end{array}$ & $\begin{array}{l}\text { Site } 5 \text { (Wolf et al } \\
\text { 1996) }\end{array}$ & $\begin{array}{l}\text { Site } 6 \text { (Fiatarone et } \\
\text { al 1994) }\end{array}$ & $\begin{array}{l}\text { Site } 8 \text { (Wolfson et al } \\
1993)^{20}\end{array}$ \\
\hline $\begin{array}{l}\text { Number and } \\
\text { age of } \\
\text { participants }\end{array}$ & $\begin{array}{l}1323 \text { participants } \\
\text { aged at least } 75 \text {, or } \\
65 \text { if they had } \\
\text { fallen within the } \\
\text { previous month }\end{array}$ & $\begin{array}{l}300 \text { participants } \\
\text { aged at least } 70\end{array}$ & $\begin{array}{l}100 \text { participants } \\
\text { aged } 65-85\end{array}$ & $\begin{array}{l}194 \text { participants } \\
\text { aged at least } 60\end{array}$ & $\begin{array}{l}180 \text { participants } \\
\text { aged at least } 70\end{array}$ & $\begin{array}{l}100 \text { participants } \\
\text { aged at least } 70\end{array}$ & $\begin{array}{l}120 \text { participants } \\
\text { aged at least } 75\end{array}$ \\
\hline $\begin{array}{l}\text { Exercise } \\
\text { interventions }\end{array}$ & $\begin{array}{l}4 \text { months of low } \\
\text { level endurance } \\
\text { followed by } \\
\text { flexibility exercises }\end{array}$ & $\begin{array}{l}3 \text { months of } \\
\text { resistance, balance, } \\
\text { and flexibility } \\
\text { exercises }\end{array}$ & $\begin{array}{l}6 \text { months of } \\
\text { flexibility training } \\
\text { plus resistance } \\
\text { and/or endurance } \\
\text { exercises }\end{array}$ & $\begin{array}{l}16 \text { weeks of } \\
\text { resistance, } \\
\text { flexibility, and } \\
\text { balance training }\end{array}$ & $\begin{array}{l}15 \text { weeks of static } \\
\text { balance training on } \\
\text { a balance platform } \\
\text { or dynamic } \\
\text { exercise training } \\
\text { using Tai Chi }\end{array}$ & $\begin{array}{l}10 \text { weeks of } \\
\text { resistance training }\end{array}$ & $\begin{array}{l}13 \text { weeks of } \\
\text { balance and } \\
\text { resistance training }\end{array}$ \\
\hline
\end{tabular}

${ }^{\star}$ All participants, except those at site 4 and 6 , were living in the community. Some of the interventions were combined with other non-exercise interventions (sites 1,2 , and 6).

was to improve lower extremity muscle strength, the rate of falls was found to be higher (although not significantly) in groups receiving low intensity exercise. ${ }^{22}$ In another study no significant effect on falls was detected overall, although there was a significant drop in falls due to loss of balance. ${ }^{24}$ In a third study balance training was found to reduce the rate of falls in platform sensory tests. ${ }^{23}$

Thirteen randomised controlled trials were identified which evaluated the modifying effect of exercise interventions on potential risk

Table 2 Summary of (non-FICSIT) randomised controlled trials of exercise interventions where falls or injuries related to falls are measured

\begin{tabular}{|c|c|c|c|c|}
\hline Author, country, and objectives & $\begin{array}{l}\text { Population, setting, and } \\
\text { intervention }\end{array}$ & Design & Key result & Commentary \\
\hline $\mathrm{Hu}$ and Woollacot $(1994)^{23}$ & $\begin{array}{l}\text { Older healthy people age } \\
65-90 \text { living in the } \\
\text { community }\end{array}$ & $\begin{array}{l}\text { Method of } \\
\text { randomisation: not } \\
\text { stated }\end{array}$ & $\begin{array}{l}\text { The I group showed significant } \\
\text { improvement in stability in } 5 \text { of } \\
\text { the } 8 \text { conditions }(P<0.006) \text { and } \\
\text { fell less often during platform } \\
\text { sensory tests and stood longer on } \\
\text { one leg than the } C \text { group } \\
(P<0.001)\end{array}$ & $\begin{array}{l}\text { The I group experienced a greater } \\
\text { number of falls in the platform } \\
\text { sensory tests at baseline which was } \\
\text { adjusted for in the analysis }\end{array}$ \\
\hline $\begin{array}{l}\text { USA } \\
\text { To determine the effects of } 10 \text { hour } \\
\text { standing balance training on } \\
\text { balance ability in a group of } \\
\text { healthy older people }\end{array}$ & $\begin{array}{l}\text { Setting: research centre } \\
\text { I: a } 10 \text { hour training } \\
\text { programme over a } 15 \text { day } \\
\text { period delivered by a } \\
\text { physical trainer }(n=12) \\
\text { C: no intervention }(n=12)\end{array}$ & Follow up: 4 weeks & Dropouts: $\mathrm{I}=17 \%, \mathrm{C}=17 \%$ & $\begin{array}{l}\text { Dropouts were not included in any } \\
\text { of the analyses }\end{array}$ \\
\hline Lord et al $(1995)^{24}$ & $\begin{array}{l}\text { Women aged } 60 \text { to } 85 \\
\text { years, living independently } \\
\text { in one community }\end{array}$ & $\begin{array}{l}\text { Method of } \\
\text { randomisation: not } \\
\text { stated }\end{array}$ & $\begin{array}{l}\text { The I group showed improved } \\
\text { performance in all } 5 \text { strength } \\
\text { measures, reaction time, } \\
\text { neuro-muscular control, and body } \\
\text { sway }(\mathrm{P}<0.05, \mathrm{P}<0.01))\end{array}$ & $\begin{array}{l}\text { Slight differences in reported } \\
\text { medical conditions, falls, } \\
\text { instability, drug use, and inactivity } \\
\text { between } \mathrm{C} \text { and I groups at baseline }\end{array}$ \\
\hline Australia & $\begin{array}{l}\text { I: a } 1 \text { hour exercise session, } \\
\text { twice weekly for } 10 \text { to } 12 \\
\text { week terms, run by exercise } \\
\text { trainers }(n=100)\end{array}$ & $\begin{array}{l}\text { Follow up: } 12 \\
\text { months }\end{array}$ & $\begin{array}{l}\text { There were no significant } \\
\text { differences between the I and C } \\
\text { groups in the percentage of falls. } \\
\text { However, the groups differed in } \\
\text { types of falls (balance fall } 5 \% v \\
17 \% \text { for I and C groups, } \\
\text { respectively). Average attendance } \\
\text { was } 73 \%\end{array}$ & $\begin{array}{l}\text { Dropouts not included in any of } \\
\text { the analyses }\end{array}$ \\
\hline $\begin{array}{l}\text { To determine whether a } 12 \text { month } \\
\text { programme of regular exercise } \\
\text { can improve balance, reaction } \\
\text { time, neuro-muscular eontrol, and } \\
\text { muscle strength and reduce the } \\
\text { rate of falling in older women }\end{array}$ & C: no intervention $(n=97)$ & & Dropouts: $\mathrm{I}=25 \% \mathrm{C}=22 \%$ & \\
\hline Reinsch et al $(1992)^{22}$ & $\begin{array}{l}\text { Adults aged } 60 \text { years and } \\
\text { over in senior centres }\end{array}$ & $\begin{array}{l}\text { Method of } \\
\text { randomisation: not } \\
\text { stated }\end{array}$ & $\begin{array}{l}\text { The rate of at least one fall was } \\
25 \% \text { in the E group, } 19 \% \text { in the } \\
\text { CB group, } 37 \% \text { in the EC group, } \\
\text { and } 19 \% \text { in the } C \text { group }\end{array}$ & $\begin{array}{l}\text { The } 2 \text { groups (E) (EC) involved in } \\
\text { exercise had the highest rates of } \\
\text { falling }\end{array}$ \\
\hline North America & $\begin{array}{l}\text { Exercise }(\mathrm{E}) \text { : low intensity } \\
\text { programme to prevent falls } \\
(\mathrm{n}=4 \text { centres, } 57 \text { people) }\end{array}$ & $\begin{array}{l}\text { Randomised by } \\
\text { senior centre }\end{array}$ & $\begin{array}{l}\text { There were no significant } \\
\text { differences in the levels of injuries } \\
\text { or on measures of balance and } \\
\text { strength }\end{array}$ & Intention to treat analysis used \\
\hline $\begin{array}{l}\text { To assess the effectiveness of } \\
\text { exercise and cognitive behavioural } \\
\text { programmes in reducing falls and } \\
\text { injuries and improving balance } \\
\text { and strength in older people }\end{array}$ & $\begin{array}{l}\text { Cognitive behavioural } \\
(\mathrm{CB}) \text { : health and safety } \\
\text { education to prevent falls } \\
\text { and relaxation training ( } \mathrm{n}= \\
4 \text { centres, } 51 \text { people) } \\
\text { Exercise and cognitive } \\
\text { behavioural }(\mathrm{EC}) \text { : } \\
\text { combined programme of } \\
\text { exercise, relaxation, and } \\
\text { discussion ( } \mathrm{n}=4 \text { centres, } \\
72 \text { people) } \\
\text { C: discussion of health } \\
\text { related topics (n }=4 \\
\text { centres, } 50 \text { people) }\end{array}$ & Follow up: 1 year & $\begin{array}{l}\text { Dropouts: } \mathrm{E}=23 \%, \mathrm{CB}=27 \%, \\
\mathrm{EC}=15 \%, \mathrm{C}=16 \%\end{array}$ & \\
\hline
\end{tabular}


factors for falling. Seven studies showed a decrease in risk factors for falls with exercise, ${ }^{25-31}$ four showed no significant effect other than improvements in strength, ${ }^{32-35}$ one showed an improvement in flexibility, ${ }^{36}$ and one reported a deterioration in postural sway with exercise. ${ }^{37}$

Overall, despite the variable quality of these studies, their results together with the results from the FICSIT trials provide reasonable evidence to suggest that exercise may help reduce the risk of falls and some risk factors for falls. Those interventions which use balancing exercise, strength training, and low impact aerobic exercise may be the most effective.

\section{COST AND BENEFITS OF EXERCISE}

An increase in physical activity is likely to have other benefits for older people. A meta-analysis has shown that exercise can reduce the risk of coronary heart disease. ${ }^{38} \mathrm{~A}$ recent review of the healthcare costs and benefits of exercise reported that in people over 45 years of age, exercise results in savings in the cost of health care by reducing in morbidity from coronary heart disease, falls, etc. ${ }^{39}$ However, the type of exercise must be appropriate to the level of health and fitness of the person. A recent review of trials evaluating the effectiveness of methods to promote exercise in community based adults (of which some studies were in people over 55 years of age) concluded that it is possible to both increase and maintain levels of activity. This is best achieved when exercise is of moderate intensity, can be performed either alone or with others, is enjoyable and convenient, and can be completed in three sessions a week. Professional support or interaction with a healthcare professional seems to be important in promoting exercise and adherence. $^{40}$

HOME ASSESSMENTS AND SURVEILLANCE

Table 3 shows the results of randomised controlled trials which have evaluated home assessment and surveillance interventions. ${ }^{171-48}$ All studies involved visiting older people at home, assessment of the safety of the home environment, followed by a range of interventions such as safety checks and necessary modifications, referral to care, and recommendations for exercise. All these studies took place in North America except for one in the United Kingdom. ${ }^{43}$

In one study, which included over 2000 people, it was found that participants who were offered a home intervention to remove and repair safety hazards showed a reduction in falls compared with controls. ${ }^{47}$ Similarly, in a study in which the intervention involved trained volunteers visiting older people at home, one third of the number of falls were reported compared with controls. ${ }^{42}$ A multifactorial intervention with home visits from nurses was also associated with a reduced number of falls in the first year of follow up. ${ }^{48}$ However, this effect was not sustained at two years, suggesting that the effects may be lost if the intervention is discontinued. In another multifactorial intervention in which nurses and physiotherapists were responsible for implementation, interventions were tailored to individual risk factors such as multiple drug use, use of sedatives or hypnotics, postural hypotension, etc. The rate of reported falls was reduced by $21 \%{ }^{17}$ The two other large trials did not find any effect of home assessment on the rate of falls. ${ }^{41} 43$

\section{Effectiveness of interventions to reduce injury from falls}

DIETARY INTERVENTIONS

Reduced concentrations of vitamin D are associated with increased bone loss, an important risk factor for bone fractures, especially in older women. Vitamin D is one of several agents which can reduce bone loss in healthy postmenopausal women, particularly in the winter ${ }^{49}$ and may therefore reduce the risk of fractures in those who fall.

A recent Cochrane Collaboration systematic review $^{50}$ found two large randomised controlled trials which assessed the effect of oral vitamin $\mathrm{D}$ and calcium supplements on frail women in nursing homes ${ }^{51}$ and oral vitamin $\mathrm{D}$ alone. ${ }^{52}$ Vitamin $\mathrm{D}$ given with calcium in doses between a quarter to a third higher than the current United Kingdom recommended daily allowances seemed to reduce the number of people who had one or more fractures by $20 \%$ over a three year period $(\mathrm{P}<0.02) .^{51}$ However, when given in lower doses, vitamin $\mathrm{D}$ by itself did not show a protective effect. $^{52}$ The only trial to evaluate vitamin $\mathrm{D}$ given as an annual injection reported a significant drop in the fracture rate. ${ }^{53}$ However, this study was not properly randomised, but points to the need for replication in a better trial. The review also showed that dietary calcium supplement alone may be effective in reducing symptomatic fractures $(\mathrm{OR}=0.37 ; 95 \% \mathrm{CI} 0.4-0.97) .{ }^{50}$

This review shows that there is potential to prevent fractures in older people with vitamin $\mathrm{D}$, or calcium, or both. One possible way to implement this intervention would be to promote exposure to sunlight and increased consumption of dairy products. However, dietary supplements in older people at high risk of fractures may be a more effective option. $^{54}$

\section{HIP PROTECTORS}

A Danish randomised controlled trial evaluated the use of external hip protector pads to prevent injury from falls in people in residential nursing homes aged 69 years and over (table 4). The risk of a hip fracture in those wearing hip pads was more than halved (age adjusted risk ratio $(\mathrm{RR})=0.4 ; 95 \% \mathrm{CI}$ $0.18-0.82) .{ }^{55}$ No fractures occurred in anyone wearing the pads at the time of a fall. Although, this seems a promising intervention in those at high risk of a fall the extent to which protection pads are generally acceptable and would be worn by older people living in the community is unclear. One of the FICSIT trials is designed to explore the acceptability of hip protectors in community and residential settings. ${ }^{56}$ 


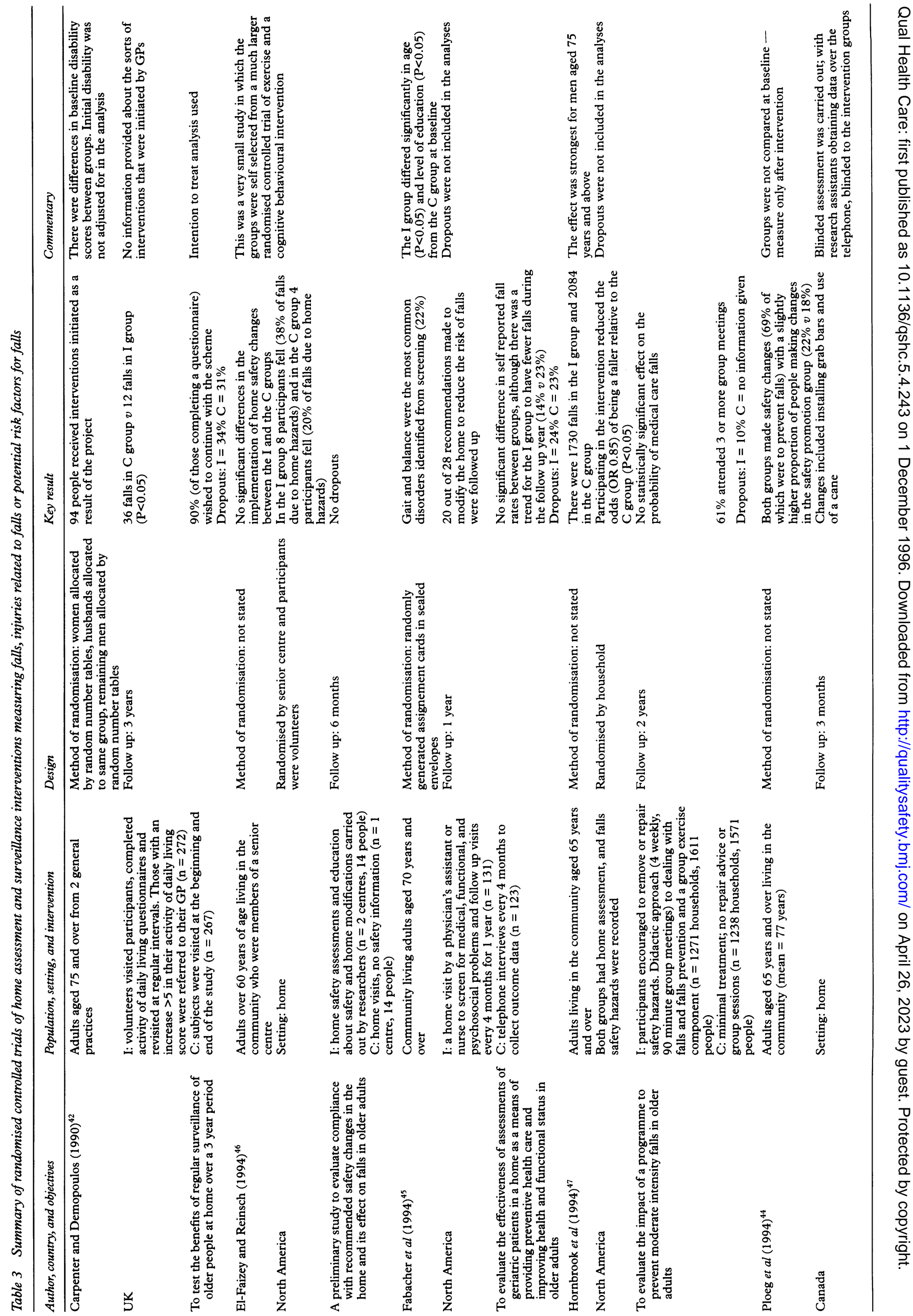



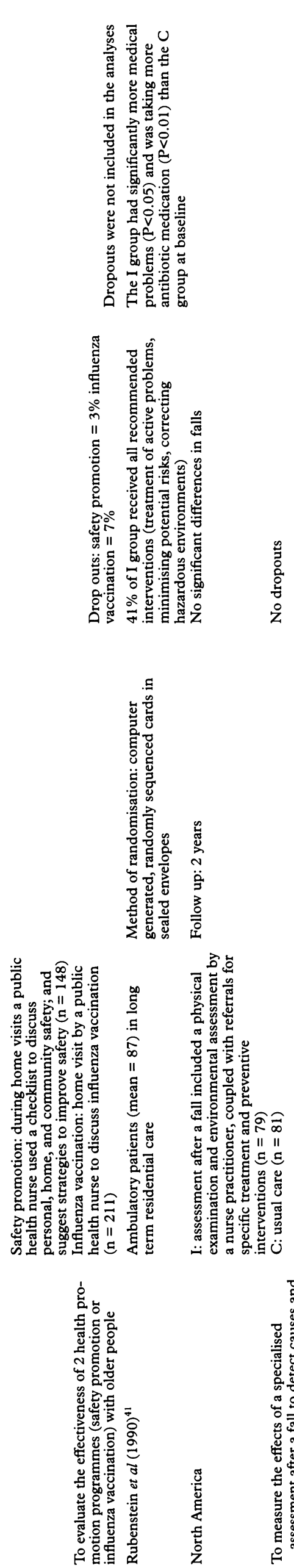
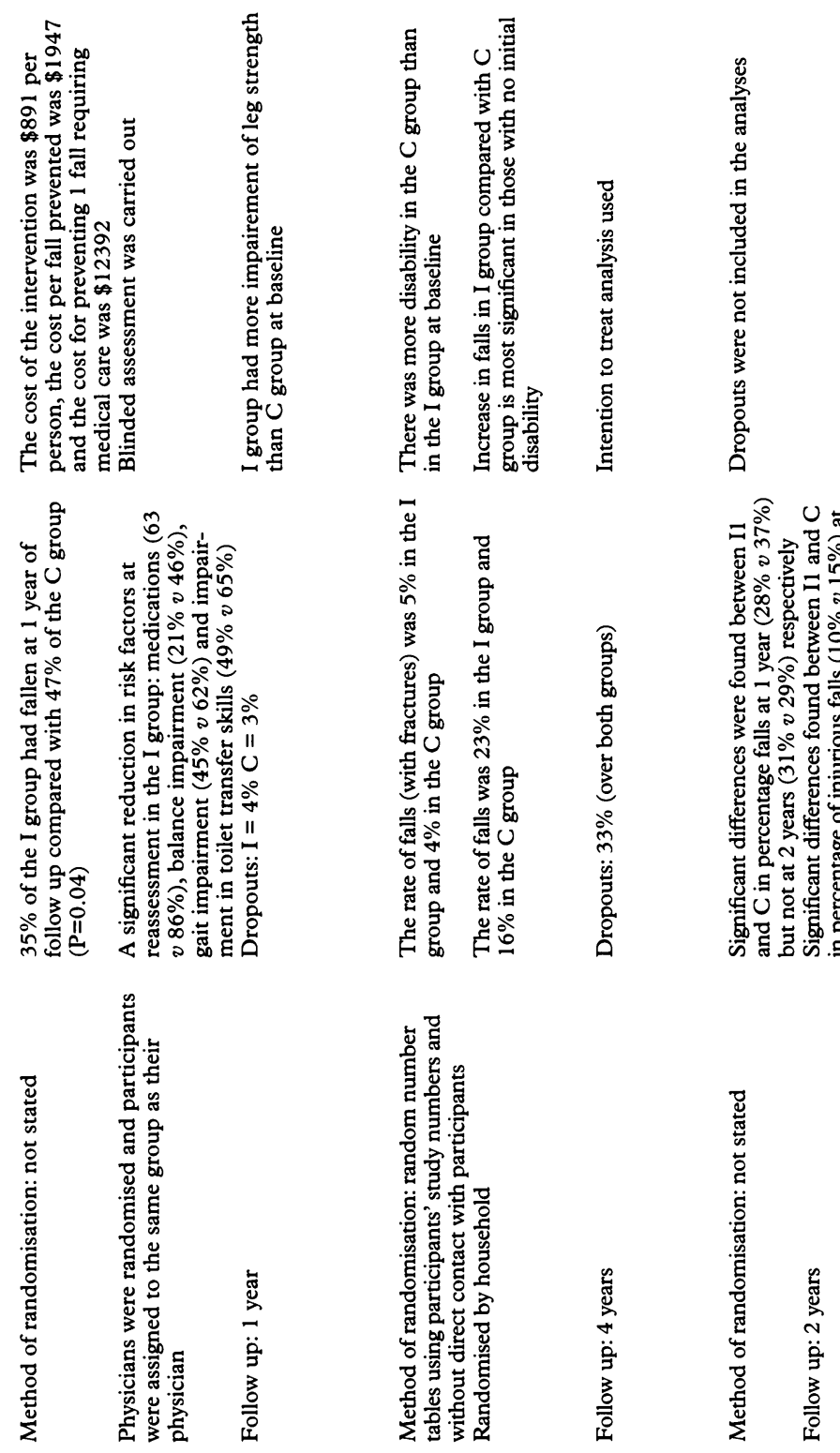

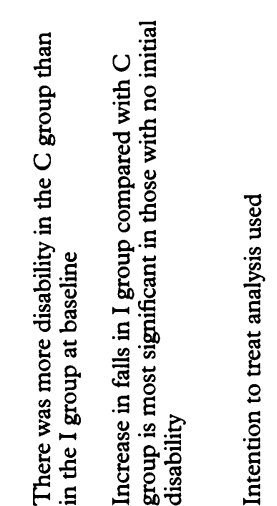

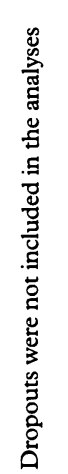

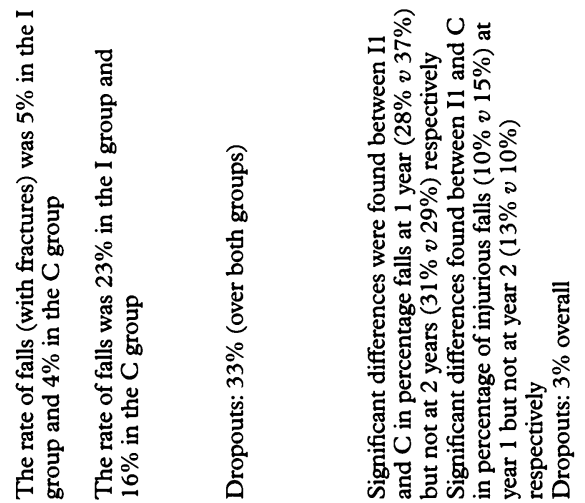

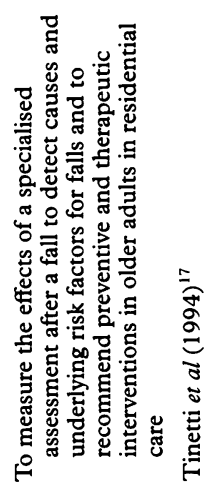
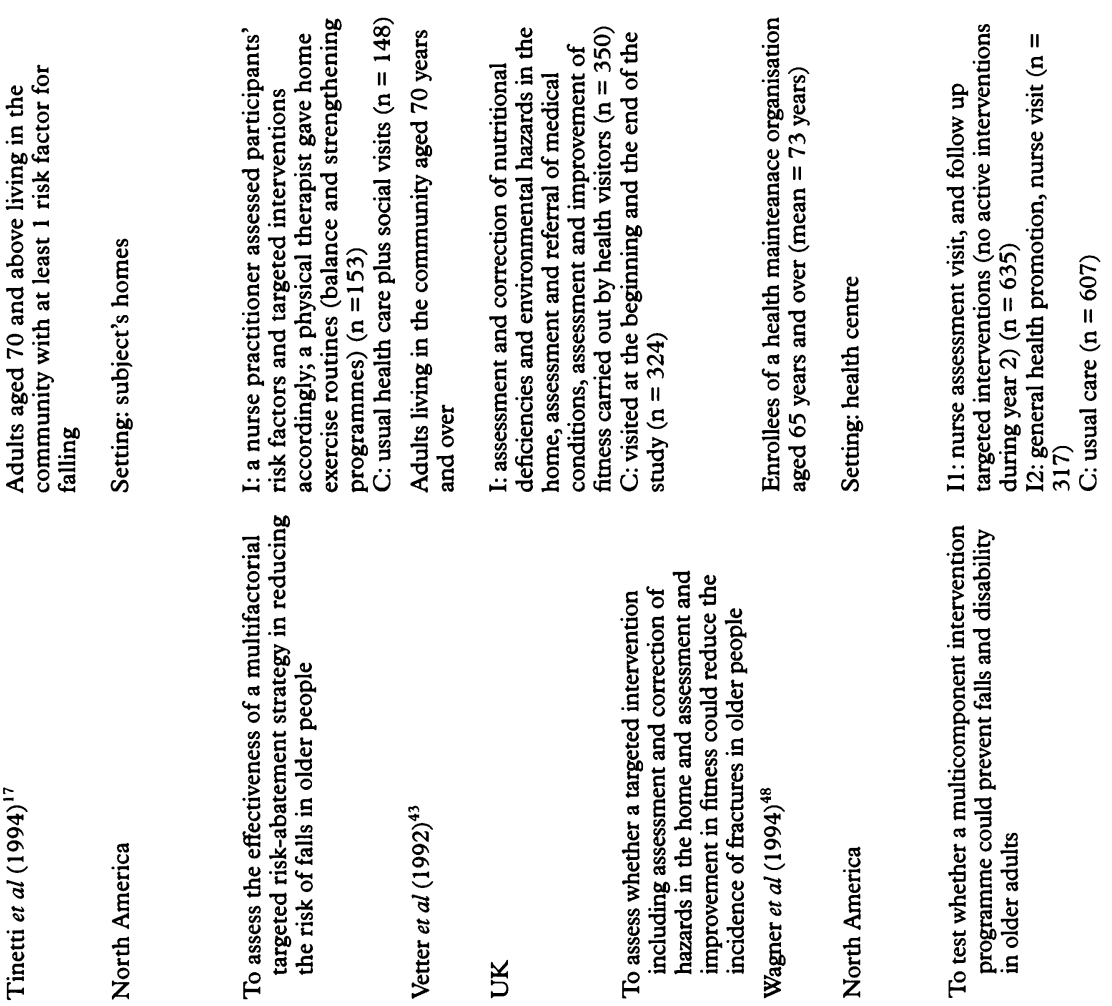

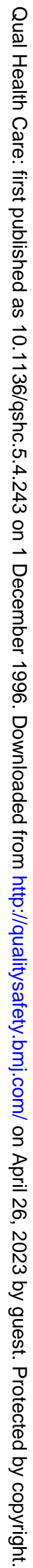


Table 4 Summary of randomised controlled trials of hip protector pads to reduce injury from falls

\begin{tabular}{|c|c|c|c|c|}
\hline Author, country, and objectives & $\begin{array}{l}\text { Population, setting, and } \\
\text { intervention }\end{array}$ & Design & Key result & Commentary \\
\hline Lauritzen et al (1993) & $\begin{array}{l}\text { Residents of a nursing home } \\
\text { aged } 69 \text { years and over }\end{array}$ & $\begin{array}{l}\text { Method of randomisation: a } \\
\text { ward was selected when its } \\
\text { number was drawn by an } \\
\text { independent doctor }\end{array}$ & $\begin{array}{l}\text { In the I group there were } 8 \text { hip } \\
\text { and } 15 \text { non-hip fractures. In } \\
\text { the } C \text { group there were } 31 \text { hip } \\
\text { and } 27 \text { non-hip fractures }\end{array}$ & $\begin{array}{l}\text { The risk of hip fracture in the I } \\
\text { group was reduced by } 53 \% \\
\text { and } 9 \text { hip fractures were } \\
\text { estimated to have been avoided }\end{array}$ \\
\hline Denmark & $\begin{array}{l}\text { I: an external hip protector } \\
\text { was worn to divert a direct } \\
\text { impact away from the greater } \\
\text { trochanter during falls. The } \\
\text { protector was fixed in special } \\
\text { underwear ( } \mathrm{n}=10 \text { wards, } 247 \\
\text { people) }\end{array}$ & Randomised by ward & $\begin{array}{l}\text { People in the I group with } \\
\text { fractures were not wearing hip } \\
\text { protectors at the time of } \\
\text { fracture }\end{array}$ & \\
\hline $\begin{array}{l}\text { To investigate the effect of } \\
\text { external hip protectors on } \\
\text { the prevention of fractures } \\
\text { in older residents of nursing } \\
\text { homes }\end{array}$ & $\begin{array}{l}\text { C: usual care }(n=18 \text { wards, } \\
418 \text { people) }\end{array}$ & Follow up: 11 months & $\begin{array}{l}\text { The relative risk of hip fracture } \\
\text { in the I group (adjusted for } \\
\text { skewness in age) was } 0.41 \\
(95 \% \text { CI } 0.18 \text { to } 0.82 \text { ) } \\
\text { Dropouts: not stated }\end{array}$ & \\
\hline
\end{tabular}

\section{Conclusions}

Balancing, low impact aerobics, and muscle strengthening exercise may reduce the rate of falls in older people with reasonable levels of fitness. Research is needed to identify the most cost effective exercise programmes which could, for example, explore ways of promoting uptake and long term adherence, and evaluate the relative advantage of different types of exercise.

Home visiting to identify and remedy environmental and personal risks of falling may also reduce the risk of falling. The changes could include removal of throw rugs and objects in pathways, and the installation of improved night lights and bath non-skid mats. These changes could be carried out by health visitors, nurses, occupational therapists, or trained volunteers. Further research on applying this in the United Kingdom is needed.

High dose vitamin D supplements with or without calcium seem to be effective in reducing risk of fracture, although major trials to assess the cost effectiveness of vitamin $\mathrm{D}$ and calcium supplements are needed. In particular, the potential value of an annual vitamin $D$ injection should be explored.

The use of hip pad protectors for people in institutional care who are at high risk of falling may significantly reduce the rate of injury due to falls. Their acceptability in other settings needs to be evaluated.

1 Preventing falls and subsequent injury in older people. Effective Health Care 1996;2:1.

2 Family Policy Studies Centre. Factsheet 1: putting families on the map. London: Family Policy Studies Centre, 1994

3 Askham J, Glucksman, E, Owens O, Swift C, Tinker A, Yu $\mathrm{G}$. A review of research on falls among elderly people. London: Age Concern Institute of Gerontology, 1990

4 Health of the Nation. A strategy for health in England. London: HMSO, 1992 .

5 Department of Trade and Industry. HASS listings for 1993 , for males and females aged 50 and above for falls. London: Consumer Unit, DTI, 1993.

6 Lilley JM, Arie T, Chilvers CED. Accidents involving older people: a review of the literature. Age Ageing 1995;24:346-65.

7 Hogue CC. Managing falls: the current bases for practice. In: Funk SG, Tornquist EM, Champagne MT, Wiese RA eds. Key aspects of elder care: managing falls, incontinence and cognitive impairment. New York: Springer, 1992.

8 Rhymes J, Jaeger R. Falls: prevention and management in the institutional setting. Clinics Geriatr Med 1988;4:613 22 .

9 Tinetti ME. Factors associated with serious injury during falls by ambulatory nursing home residents. $\mathscr{f} \mathrm{Am}$ Geriat Soc 1987;35:644-8
10 Tinetti ME, Speechley M, Ginter SF. Risk factors for falls among elderly persons living in the community: $N^{\prime} \mathrm{Engl} Y$ Med 1988:319:1701-7.

11 Kellog International Work Group on the Prevention of Falls by the Elderly. The prevention of falls in later life. Danish Medical Bulletin 1987;4:1-24.

12 Gillespie LD. Risk factors for falling in community dwelling elderly: quality of the literature and the role of muscle strength. Newcastle, New South Wales, Australia: University of Newcastle, 1996. [Thesis in preparation.]

13 Province M, Hadley E, Hornbrook M, Lipsitz L, Miller J, Mulrow C, et al, for the FICSIT Group. The effects of exercise on falls in elderly patients. A preplanned meta-analysis of the FICSIT trials. $\mathscr{F A M A}$ 1995;273:1341 7

14 Mulrow C, Gerety MB, Kanten D, Cornell JE, DeNino LA, Chiodo $\mathrm{L}$, et al. A randomized trial of physical rehabilitation for very frail nursing home residents. $7 A M A$ 1994;271:519-24.

15 Fiatarone MA, O'Neill EF, Ryan ND, Clements KM, Solares GR, Nelson ME, et al. Exercise training and nutri-
tional supplementation for physical frailty in very elderly tional supplementation for physical frail
people. N Engl f Med 1994;330:1770-5.

16 Hornbrook MC, Stevens VJ, Wingfield DJ. Seniors program for injury control and prevention. $\mathcal{F} \mathrm{Am}$ Geriat Soc 1993;41:309-14.

17 Tinetti ME, Baker DI, McAvay G, Claus EB, Garrett P, Gottschalk $M$, et al. A multifactorial intervention to reduce the risk of falling among elderly people living in the community. $N$ Engl $\mathcal{F}$ Med 1994;331:821-7.

18 Buchner DM, Cress ME, Wagner EH, de Lateur BJ, Price $\mathrm{R}$, Abrass IB. The Seattle FICSIT/move it study: the effect of exercise on gait and balance in older adults. F $\mathrm{Am}$ Geriatr $\operatorname{Soc} 1993 ; 41: 321-5$.

19 Wolf SL, Barnhart HX, Kutner NG, Green RC, McNeely E, Coogler $\mathrm{C}, \mathrm{Xu}$ T, the Atlanta FICSIT Group. Reducing frailty and falls in older persons: an investigation of Tai $\mathrm{Ch}$ and computerised balance training. $7 \mathrm{Am}$ Geriatr $S_{0}$ 1996;44:489-97.

20 Wolfson LI, Whipple R, Judge J, Amerman P, Derby C, King $M$. Training balance and strength in the elderly to improve function. 7 Am Geriatr $S_{0 c}$ 1993; $\mathbf{4 1 : 3 4 1 - 3 . ~}$

21 Pacala JT, Judge JO, Boult C. Factors affecting sample selection in a randomised trial of balance enhancement: the FICSIT study. $\mathcal{F}$ Am Geriatr Soc 1996; 44:377-82

22 Reinsch S, MacRae P, Lachenbruch PA, Tobis JS. Attempts to prevent falls and injury: a prospective community study. Gerontologist 1992;32:450-6.

$23 \mathrm{Hu} \mathrm{M}$, Woollacott MJ. Multisensory training of standing balance in older adults. 1 Postural stability and one-leg stance balance. F Gerontol 1994;49:m52-61.

24 Lord SR, Ward JA, Williams P, Strudwick M. The effect of a 12 month exercise trial on balance, strength and falls in older women: a randomised controlled trial. $7 \mathrm{Am}$ Geriat Soc 1995;43:1 198-206.

25 Era P. Posture control in the elderly. International fournal of Technology and Aging 1988;1:166-79.

26 Hopkins DR, Murrah B, Hoeger WWK, Rhodes RC. Effect of low-impact aerobic dance on the functional fitness of elderly women. Gerontologist 1990;30:189-92.

27 Sauvage LR Jr, Myklebust BM, Crow-Pan J, Novak S, Millington $\mathrm{P}$, Hoffman MD, et al. A clinical trial of strengthening and aerobic exercise to improve gait and balance in elderly male nursing home residents. Am $f$ Phys $\mathrm{Med}$ Rehabil 1992;71:333-42

28 Judge OJ, Lindsey C, Underwood $M$, Winsemius D. Balance improvements in older women: effects of exercise training. Physical Training 1993;73:254-62.

29 McMurdo MET, Rennie L. A controlled trial of exercise by residents of old people's homes. Age Ageing 1993;22:11-5.

30 Nelson M, Fiatarone M, Morganti C, Trice I, Greenberg R, Evans W. Effects of high-intensity strength training on multiple risk factors for osteoporotic fractures randomised controlled trial. $\mathcal{F A M A} 1$ 1994;272:1909-14.

31 Skelton DA, McLaughlin AW. Training functional ability in old age. Physiotherapy' 1996;82:159-67. 
32 Lichtenstein MJ, Shields SL, Shiavi RG, Burger C. Exercise and balance in aged women: a pilot controlled clinical and balance in aged women: a pilot
trial. Arch Phys Rehabil 1989;70:138-43.

33 Topp R, Mikesky A, Wigglesworth J, Holt W, Edwards JE. The effect of a 12 week dynamic resistance strength training program on gait velocity and balance of older adults. Gerontologist 1993;33:501-6.

34 McMurdo MET, Johnstone R. A randomised controlled trial of home exercise for elderly people with poor mobility. Age Ageing 1995;24:425-8.

35 Skelton DA, Young A, Greig CA, Malbut KE. Effects of resistance training on strength, power and selected functional abilities of women aged 75 and older. $7 \mathrm{Am}$ Geriatr Soc 1995;43:1081-7.

36 Mills RM. The effect of low-intensity aerobic exercise on muscle strength, flexibility and balance among sedentary elderly persons. Nurs Res 1994;43:207-11.

37 Crilly RG, Willems DA, Trenholm KJ, Hayes KC, Delaquerriere-Richardson LFO. Effect of exercise on postural sway in the elderly. Gerontology 1989;35:137-43.

38 Berlin JA, Colditz GA. A meta analysis of physical activity in the prevention of coronary heart disease. Am $\mathcal{F}$ Epidemio 1990;132:639-46.

39 Nicholl JP, Coleman P, Brazier JE. Health and healthcare costs and benefits of exercise. Pharmacoeconomics 1994; 5:109-22.

40 Hillsdon $M$, Thorogood $M$, Anstiss $T$, Morris J. Randomised controlled trials of physical activity promotion in fomised controlled trials of physical activity promotion in free living populations:
Health $1995 ; 49: 448453$.

41 Rubenstein LZ, Robbins AS, Josephson KR, Schulman BL, Osterweil $\mathrm{D}$. The value of assessing falls in an elderly population: a randomized clinical trial. Ann Intern Med 1990;113:308-16.

42 Carpenter GI, Demopoulos GR. Screening the elderly in the community: controlled trial of dependency surveillance using a questionnaire administered by volunteers. $B M \mathcal{F}$ 1990;300:1253-6.

43 Vetter NJ, Lewis PA, Ford D. Can health visitors prevent fractures in elderly people? BMF 1992;304:888-90.

44 Ploeg S, Black ME, Hutchison BG, Walter SD, Scott FE Chambers LW. Personal, home and community safety
Che promotion with community-dwelling elderly persons: response to public health nurse intervention. Can $\mathcal{F}$ Public Health 1994;85:188-91.

45 Fabacher D, Josephson K, Pietruszka, Linderborn K, Mor- ley JE, Rubenstein LZ. An in-home preventive assessment program for independent older adults: a randomized conprogram for independent older adults: a random
trolled trial. $\mathcal{A} \mathrm{Am}$ Geriatr Soc 1994;42:630-8.

46 El-Faizy M, Reinsch S. Home safety intervention for the prevention of falls. Physical and Occupational Therapy in Geriatrics 1994;12:33-49.

47 Hornbrook MC, Stevens VJ, Wingfield DJ, Hollis JF, Greenlick MR, Ory MG. Preventing falls among community-dwelling older persons: results from a randomized trial. Gerontologist 1994;34:16-23.

48 Wagner EH, LaCroix AZ, Grothaus L, Leveille SG, Hecht $\mathrm{JA}$, Artz $\mathrm{K}$, et al. Preventing disability and falls in older adults: a population-based randomized trial. Am $\mathcal{f}$ Public Health $1994 ; 84: 1800-6$.

49 Dawson-Hughes B, Dallal GE, Krall EA, Harris S, Sokoll LJ, Falconer G. Effect of vitamin D supplementation on wintertime and overall bone loss in healthy postmenopausal women. Ann Intern Med 1991;115:505-12.

50 Gillespie WJ, Henry DA, O'Connell DL, Robertson J. Vitamin $D$, vitamin $D$ analogues and calcium in prevention of fractures in involutional and post-menopausal osteoporosis. Cochrane Database of Systematic Reviews 1996;3.

51 Chapuy MC, Arlot ME, Duboeuf F, Brun J, Crouzet B, Arnaud S, et al. Vitamin D3 and calcium to prevent hip
fractures in elderly women. $N$ Engl f Med 1992;327:163742.

52 Lips P, Graafmans WC, Ooms ME, Bezemer PD, Bouter LM. Vitamin D supplementation and fracture incidence in trial. The effect of vitamin D supplementation on the incidence of hip fractures in elderly people. Ann Intern Med 1996;124:400-6.

53 Heikinheimo RJ, Inkovaara JA, Harju EJ, Haavisto MV, Kaarela RH, Kataja JM, et al. Annual injection of vitamin $\mathrm{D}$ and fractures of aged bones. Calcif Tiss Int 1992;51:10510.

54 Allison S. Cost benefits of nutritional support. Paper presented to a scientific nutrition workshop: a positive contribution to NHS cost containment. London: Medical Society of to NHS cost cont

55 Lauritzen JH, Petersen MM, Lund B. Effect of external hip protectors on hip fractures. Lancet 1993;341:11-3.

56 Wallace R, Ross J, Huston J, Kundel C, Woodworth G. Iowa FICSIT trial: the feasibility of elderly wearing a hip joint protective garment to reduce hip fractures. $\mathcal{f} \mathrm{Am}$ Geriatr Soc 1993;41:341-3. 